tution; Washington, D.C.; general secretary, Prof. F. E. Clements, University of Minnesota; secretary of the council, Prof. J. Zeleny, University of Minnesota.

Grants were made to the Concilium Bibliographicum Zoologicum at Zürich, and to individuals as follows:-To Prof. T. D. A. Cockerell, to assist in an investigation of the microscopic structure of the scales of different genera of fishes; to Dr. W. D. Hoyt, to assist in an investigation upon environic relations of the alga Dictyota, which develops a rhythm in fruiting coincident with every alternate springtide; to Prof. G. J. Peirce, to assist in investigations of organisms inhabiting the alternately filling and drying salt-water pools along the coasts of central California. The last two grants are to be expended under the supervision of the standing committee upon the relation of plants to climate.

\section{THE MEAN HEIGHT OF THE ANTARCTIC CONTINENT.}

PROF. W. MEINARDUS gives the results of an estimate of the mean elevation of the central core of the Antarctic land mass, based on the distribution of atmospheric pressure and consequent exchange of air between the two hemispheres, in the November and December numbers of Petermann's Mitteilungen. Extending Spitaler's results with the help of Mohn's discussion of the Fram observations, and Baschin's maps of the southern oceans, Prof. Meinardus finds that, while the mean pressure (not reduced to sea-level) is $0.85 \mathrm{~mm}$. higher in January than in July between latitudes $0^{\circ}$ to $80^{\circ} \mathrm{N}$., in the zone $0^{\circ}$ to $50^{\circ} \mathrm{S}$. it is $2^{\circ} 14 \mathrm{~mm}$. lower. In higher southern latitudes, as far as $60^{\circ} \mathrm{S}$. lat., the January pressure is $0.73 \mathrm{~mm}$. less than the July, and from $60^{\circ} \mathrm{S}$. to the Antarctic circle the relation is almost one of equality. Hence, allowing for proportional areas, it follows that within the Antarctic circle the true atmospheric pressure must be II $\mathrm{mm}$. higher in January than in July.

Observation, however, has so far failed to reveal the existence of this excess; the diminution of the southward temperature gradient and consequent weakening of easterly winds on the edge of Antarctis in summer render it probable that, as in the north polar region, the pressure at sea-level is actually lower in summer than in winter. The discrepancy can be explained by assuming a mean elevation for the area within the Antarctic circle, and taking $-3^{\circ}$ and $-26^{\circ}$ as the mean temperatures for January and July respectively, Porf. Meinardus gets a value for this of 1328 metres, or, as a second approximation with temperatures $-6^{\circ}$ and $-29^{\circ}, 135^{\circ}$ metres, with a probable error of \pm 150 metres. Having regard to the proportion of the area known to be covered by sea, the land surface is taken as $I_{4}$ millions of square kilometres (Bruce and Krümmel), and its mean height then becomes 2000 metres, with a probable error of \pm 200 metres.

Recent explorations suggest that this value is not far from the truth, the covering of inland ice being, as in Greenland, an important factor. If it is approximately correct, Antarctica is the largest mass of raised land in the world; it is half as large again as Europe, and Asia, the highest of the known continents, has a mean elevation of less than half (950 metres). The accepted value of the mean height of the land surface of the world, 700 metres, is raised to 825 metres, and the mean level of the physical surface of the globe from 205 to 240 metres.

NO. 2099, VOL. 82]

\section{THE NATURAL HISTORY MUSEUM.}

I N NATURE of December 16 and 30 we reprinted from the Times some letters dealing with this subject. We were under the impression that the main point of contention was the complete separation of the Natural History Museum from the other collections in the British Museum, as recommended by the Duke of Devonshire's Royal Commission in 1874 , to go no further back.

Sir Archibald Geikie has since pointed out to us that the questions put to him in the letter from the Speaker of the House of Commons to which he replied "were entirely in reference to the relations between the Trustees and the Museum," and that, this being so, we should have given a letter from Mr. Carruthers dealing with this point which had also appeared in the Times. We therefore now reprint the letter in question :-

Sir,-The President of the Royal Society, Sir Archibald Geikie, has expressed clearly his view on the questions in relation to the administration of the British Museum recently raised in your columns. A former eminent President, Prof. Huxley, was brought by his experience as Trustee, as Sir Archibald has been, to similar favourable conclusions.

It was notorious that Prof. Huxley severely criticised the governing body of the Natural History Departments of the British Museum. He had expressed this view to me personally, but, after he had been some time a Trustee, he spontaneously informed me that he had totally changed his opinion, and that he could not imagine a more efficient system of administration. This, I must add, was previous to 1898 .

As Keeper of Botany for twenty-four years, I cannot recall a single occasion in which my department suffered from the action of the Trustees. I always found them intelligent and sympathetic in the affairs of the department. William Carruthers.

\section{NOTES.}

Trie council of the Royal Astronomical Society has awarded the gold medal of the society to Prof. F. Küstner, director of the University Observatory of Bonn, for his catalogue of stars, his pioneer determination of the aberration constant from motions in the line of sight, and his detection of the variation of latitude.

The Geological Society of London will this year award its medals and funds as follows :-Wollaston medal, to Prof. W: B. Scott; Murchison medal, to Prof. A. P. Coleman; Lyell medal, to Dr. A. Vaughan; Wollaston fund, to Mr: E. B. Bailey; Murchison fund, to Mr. J. W. Stather; Lyell fund, to Mr. F. R. Cowper Reed and Dr. R. Broom.

Prof. R'. Mer.dola, F.R.S., has been elected an honorary member of the Sociedad Española de Fisica y Quimica.

Prof. W. TRABERT has been appointed director of the k.k. Zentralanstalt für Meteorologie und Geodynamik at Vienna.

M. G. EIFFen has been elected president of the Meteorological Society of France for 1910, and M. Teisserenc de Bort and Dr. de Valcourt vice-presidents.

THE death is announced, at the age of ninety-one years, of Dr. George Skene Keith, formerly a well-known Edinburgh physician. Dr. Keith was the author of the book "Plea for a Simpler Life," which had a wide circulation, and of other works.

By the will of the late Sir Alfred Jones, the sum of about 500,000l. will be at the disposal of the trustees "for 